\title{
A Review of the Literature on Mathematics and Science Teacher Quality
}

\author{
Johnna J. Bolyard \\ West Virginia University \\ Patricia S. Moyer-Packenham \\ Utah State University
}

\begin{abstract}
A large body of literature exists that examines teacher quality characteristics and the relationship of indicators of those characteristics to teacher effectiveness. This existing research literature broadly views teacher quality research without illuminating specific areas of teacher quality, such as mathematics and science. In an effort to focus the literature base for researchers and policymakers more narrowly, this review specifically examines teacher quality as it relates to mathematics and science teaching and learning. The review highlights key policy and practitioner perspectives, provides a focused synthesis on current research findings on mathematics and science teacher quality, and suggests areas of research that are limited in the literature.
\end{abstract}

Recently, K-12 education has been engaged in a struggle to staff schools with qualified teachers, particularly in areas such as mathematics and science. This growing struggle has prompted concerns about teacher supply, as evidenced in the landmark report published by the National Commission on Teaching and America's Future (1996), and high-profile examinations of and policy statements on the status of teacher quality (Mitchell, Robinson, Plake, \& Knowles, 2001; U.S. Department of Education, 2002). These examinations are not surprising when a large body of empirical research has identified differences in the quality of the teacher as explaining more of the variation in student achievement than

Correspondence should be sent to Johnna Bolyard, Mathematics Education, Curriculum \& Instruction/Literacy Studies, West Virginia University, PO Box 6122, Morgantown, WV 26506. E-mail: johnna.bolyard@mail.wvu.edu 
any other school-based factor (Goldhaber \& Brewer, 1997b; Sanders \& Rivers, 1996; Strauss \& Sawyer, 1986). This recognition has led to major efforts funded by the federal government, under the direction of agencies such as the National Science Foundation and the Department of Education, to initiate Math and Science Partnership Programs for the purpose of improving mathematics and science teaching and learning in K-12 schools.

Researchers, policymakers, and educators have historically viewed teacher quality from differing perspectives. For example, from a researcher's point of view, teacher quality is operationalized as a construct and variables are identified and examined in relation to outcome measures. For a policymaker, teacher quality provides a benchmark against which individuals can be identified as meeting or not meeting a given standard of quality (Blank \& Langeson, 1999). School administrators view teacher quality as a means of finding the right educator (i.e., the one with the most potential, based on a set of qualities and skills) for the job. For educators in different positions within the educational system, teacher quality takes on different meanings. For the classroom teacher, teacher quality may be viewed as a continuous process of self-renewal and professional development where one works to impact and improve the quality of one's own teaching. A teacher educator may view a quality teacher as one who has a strong foundational knowledge of content and pedagogy that can be built upon and strengthened throughout his or her career.

With these perspectives in mind, it is easy to see how different views have emerged within the construct of teacher quality. Yet within these perspectives are overlapping themes which indicate that, perhaps, what appears on the surface to be a divergence of views actually masks a lack of clarity about what is meant by and known about teacher quality. Because of these differing perspectives, researchers, policymakers, and educators draw on different literature to make decisions about mathematics and science research, policy statements, and educational initiatives and interventions. Although other authors have reviewed the body of literature that identifies and examines variables believed to be indicators of teacher quality and the relationship of these variables to teacher effectiveness (Rice, 2003; Wayne \& Youngs, 2003), this existing literature broadly reviews teacher quality research without specific emphasis on any subject area. In an effort to bring together and focus these different literatures, this article specifically examines teacher quality as it relates to mathematics and science teaching and student outcomes. Our purpose was to create a document that could be used by researchers, policymakers, and educators as a summary of current findings on mathematics and science teacher quality.

In the sections that follow, we outline our methodology for selecting documents for inclusion, provide a synthesis on mathematics and science teacher quality from these documents, and summarize key findings from the research. The final section discusses general implications and suggests areas for further research. One 
important item to note is that the scope of this review did not seek to encompass all variables, actions, influences, and conditions of mathematics and science teacher quality. The primary goal of our article was to focus on individual characteristics of teachers. Therefore, the selection of literature distinguished between those studies that focused on characteristics of individual mathematics and science teachers and those that focused on characteristics of the teacher population. For example, research on characteristics of the teacher population that may influence teacher quality, such as the recruitment of a diverse teaching force and the supply and demand of the mathematics and science teacher population, was not part of this review. Although these broader issues are important, an examination of population characteristics of teachers and teacher quantity was beyond the scope of this article. This review provides a systematic and focused examination of the teacher quality literature as it relates to characteristics of mathematics and science teachers and student outcomes.

\section{METHODS}

We began our review with an exhaustive search of electronic databases. This search led us to several meta-analyses and reviews including those conducted by Rice (2003) and Wayne and Youngs (2003) on teacher characteristics and attributes; Cochran-Smith and Zeichner (2005); Wilson and Floden (2003); and Wilson, Floden, and Ferrini-Mundy (2001) on teacher preparation; and Greenwald, Hedges, and Laine (1996) on school resources. These large-scale analyses provided a foundation for further investigation into the literature. From this initial search, we began a more extensive review using basic search procedures and following standard criteria for a comprehensive literature search (Boote \& Beile, 2005). This process included library searches (both electronic and manual) in educational databases such as ERIC, PsycInfo, and Social Sciences Index using search terms including teacher, teacher characteristics, teacher quality, and teacher effectiveness. We searched online mathematics and science organizations for statements and position papers on teacher quality specific to these two disciplinary foci.

As part of the process for inclusion in this article, we were selective in including primary documents and widely available information from Web-based and library sources. Documents included from electronic formats were obtained from the main Web sites of the major agencies and organizations with the authority to speak for the organization. For example, we used the Web sites of the U.S. Department of Education, the National Science Teachers Association (NSTA), and the National Council of Teacher of Mathematics (NCTM) as sources of information on the positions of these organizations, rather than obtaining information 
from other sources that quoted, reported, or described the positions of these organizations.

In our selection of library and research publications and documents, we included works that were empirical, meta-analyses, and literature reviews that appeared as peer-reviewed documents. These resources were selected based on the methodological rigor of the studies, the frequency with which studies were cited and referenced by other researchers, and the focus of all or part of the research on characteristics of teacher quality. From these studies of general teacher quality, we further examined the studies and documents for information that identified teacher quality characteristics related to mathematics and science teachers. Because of the large number of documents uncovered, we further limited this review to research that targeted characteristics of teachers of mathematics and science, and used measures of students (i.e., mathematics and science achievement or student attitudes) as outcome variables. We chose student outcomes as the dependent variable because improving students' learning and educational experiences is a common goal among educational stakeholders. In total, we reviewed approximately 150 documents.

\section{FINDINGS}

The following sections present the findings of our review. We have organized the findings into two major sections: (a) key policy, public, and practitioner documents focused on mathematics and/or science teacher quality, and (b) relevant studies that correspond to mathematics and/or science teacher quality characteristics. In the first section, key policy, public, and practitioner documents, such as No Child Left Behind (NCLB) legislation, National Board Certification Standards, NCTM, and NSTA descriptions of teacher quality, are highlighted and discussed. In the next section, we present a review of the research on mathematics and science teacher quality using six individual teacher quality characteristics: general ability; experience; pedagogical knowledge; subject matter knowledge; certification status; and teacher behaviors, practices, and beliefs. These categories of individual teacher quality were chosen based on their frequent use in large-scale metaanalyses and reviews of the literature on general teacher quality (Cochran-Smith \& Zeichner, 2005; Darling-Hammond, 2000; Rice, 2003; Wayne \& Youngs, 2003; Wilson \& Floden, 2003; Wilson et al., 2001). Although other factors, such as professional development, have also been examined in relation to teacher quality, professional development was defined by the authors as a condition or intervention used to impact teacher quality characteristics and was beyond the scope of the current review. 


\section{Key Policy, Public, and Practitioner Documents on Mathematics and Science Teacher Quality}

Teacher quality, and specifically mathematics and science teacher quality, has been the focus of much public debate in education. Federal documents such as NCLB and related educational policies have escalated the focus on the quality and quantity of mathematics and science teachers in the United States. In response to this legislation and the surrounding discussion, several professional organizations have produced position statements outlining their view of a quality mathematics and science teacher.

\section{Federal Policy and Report Documents}

The NCLB Teacher Quality mandate states that a highly qualified teacher holds at least a bachelor's degree; holds full certification or has passed a teacher licensing examination (as dictated by a state licensing agency); and holds a license to teach that is not classified as emergency, temporary, or provisional. Further, "highly qualified" teachers must demonstrate competence in subject knowledge and teaching skills. Elementary teachers new to the profession must demonstrate competence in a subject such as mathematics, reading, writing, and other areas of the curriculum by passing a "rigorous State test" (U.S. Department of Education, 2002, p. 5). New middle or secondary teachers must demonstrate competency in all of the subjects they teach by passing a state subject test or completing a degree in the subject, coursework equivalent to a degree in the subject, or advanced certification or credentialing (U.S. Department of Education, 2002). Existing teachers must demonstrate competence either through an examination or based on a "high objective uniform State standard of evaluation" (U.S. Department of Education, 2002, p. 5). Although this portion of the general NCLB mandate does not specifically address mathematics and science teacher quality directly, its requirement of demonstrated competency in a subject area sends a clear edict to mathematics and science educators that content knowledge does matter.

Other federal documents echo NCLB's focus on the importance of quality teaching, particularly in the areas of mathematics and science. In July 1999, U.S. Secretary of Education Richard Riley announced the appointment of the National Commission on Mathematics and Science Teaching for the 21 st Century (the Glenn Commission) to investigate the quality of mathematics and science teaching in the country and to examine ways to increase the number and quality of mathematics and science teachers in K-12 schools. The resulting report, Before It's Too Late (National Commission on Mathematics and Science Teaching for the 21st Century, 2000), highlighted the importance of quality mathematics and science education in preparing students to be competitive in an increasingly global society. The report identified improvement of teaching as the best way to achieve that goal and 
described a vision of high-quality teaching that places deep content knowledge at its foundation. More recently, the 2006 American Competitiveness Initiative established the National Math Panel to bring together experts in mathematics, education, and cognitive science to make recommendations on the most effective methods for teaching mathematics (Office of the U.S. Press Secretary, 2006). The American Competitiveness Initiative calls for "Math Now" programs for the purposes of translating and disseminating the findings of the National Math Panel to classroom teachers.

\section{National Board for Professional Teaching Standards}

Another perspective on mathematics and science teacher quality is that identified by the National Board for Professional Teaching Standards as accomplished teaching. Accomplished teaching is based on a set of standards for each area of teaching and five core propositions which include that teachers are committed to their students' learning, know the content of their subjects as well as how to teach it, carefully monitor students' learning, reflect on their practices, and are members of professional learning communities (National Board for Professional Teaching Standards, 2002). For teachers of mathematics and science, there are four certificate and standards areas categorized by students' age and teachers' subject: Generalist Early Childhood (ages 3-8; includes mathematics and science), Generalist Middle Childhood Certificate (ages 7-12; includes mathematics and science), Mathematics or Science Early Adolescence Certificate (ages 1115), and Mathematics or Science Adolescence and Young Adulthood Certificate (ages 14-18+). To demonstrate accomplished teaching, teachers complete timed subject-area exams and create a teaching portfolio that contains videotapes of their teaching, evidence of student learning products, and a detailed analysis of their teaching practices. A surface examination of the requirements for highly qualified teachers (NCLB) compared with accomplished teachers (National Board for Professional Teaching Standards) appears to indicate that, in addition to a bachelor's degree, full state certification, and competency in the subject area, an accomplished teacher must document and analyze student learning and teaching practices.

\section{Professional Organizations}

Following the NCLB mandate, a variety of position papers and statements emerged from professional organizations and societies to clarify what it means to be a "highly qualified teacher of mathematics or science." These documents describe what knowledge should be demonstrated by a quality mathematics and science teacher. For example, in 1991, the Mathematical Association of America released 
A Call for Change: Recommendations for the Mathematical Preparation of Teachers of Mathematics, which called for a change in the mathematical preparation of prospective teachers. The report lists standards in seven content areas and recognizes that preparation must also include mathematical pedagogy (Leitzel, 1991). The Conference Board of Mathematical Sciences released in 2001 The Mathematical Education of Teachers. The report, described as an augmentation of the Mathematical Association of American report, focuses on two major themes: the substance of school mathematics and the nature of mathematical knowledge needed by teachers (Conference Board of Mathematical Sciences, 2001). The report recommends that mathematics coursework for prospective teachers deepen their knowledge of the mathematics they teach, focus on a coherent development of mathematical ideas, and develop the habits of mind of mathematical thinking. Further, the report recommends specific quantities of mathematics coursework for teachers at the elementary (at least 9 semester hr), middle (at least 21 semester hr), and high school levels (the equivalent of an undergraduate major), specifying that this coursework should be relevant to the mathematics that teachers will teach. Other recommendations include making teacher education an important part of the work of mathematics departments and fostering cooperation between mathematics and mathematics education faculty, two- and four-year institutions, and higher education and K-12.

The National Science Education Standards (National Research Council, 1996) describe quality science teachers as those who create supportive, active learning environments for their students, use assessments to inform and guide their teaching, participate in professional learning communities, and are committed to lifelong learning of science and science teaching and learning. The Council of Scientific Society Presidents described a "well-qualified" mathematics or science teacher as someone who understands mathematics and science deeply, uses instructional techniques that facilitate students' mathematical problem solving and communication, and commits to lifelong learning and improvement of his or her practice (Council of Scientific Society Presidents, 2004). These recommendations show that teacher quality includes teacher education courses as well as courses in the discipline.

Leading mathematics and science teacher education associations and organizations, including the NCTM, the NSTA, the Association of Mathematics Teacher Educators, and the Association for Science Teacher Education have similarly addressed issues of teacher quality in mathematics and science. NCTM (1991) outlines standards for mathematics teaching in Professional Standards for Teaching Mathematics. These standards are based on a framework for teaching that highlights the important decisions teachers make in their work including the selection of mathematical tasks designed to facilitate significant learning, establishing effective classroom discourse around mathematics, creating inviting and safe learning environments, and making informed decisions about future instructional 
goals. The Professional Standards' vision of effective professional development and training for teachers includes experiences that model good mathematics teaching, develop knowledge about mathematics, mathematics pedagogy, and students, and facilitate the continued development of teachers' practice. In a more recent position statement, titled "Highly Qualified Teachers," NCTM further outlines the qualifications required of a high school, middle school, and elementary school teacher of mathematics. These include the completion of coursework equivalent to a major in mathematics for high school teachers, coursework equivalent to at least a minor in mathematics for middle school, and at least the equivalent of three college-level mathematics courses for elementary and all other teachers of mathematics (NCTM, 2005, ๆ2). An NSTA (2004) position statement titled "Science Teacher Preparation" states that all teachers entering the profession need a deep understanding of pure and applied science and the knowledge necessary to teach it meaningfully ( $\mathbf{9} 2)$. In their position statement on science teacher preparation, the Association for Science Teacher Education (2004) describe quality science teachers as those who have deep understanding of science content, its applications, and history, as well how students learn science concepts and develop skills and dispositions necessary to engage in scientific inquiry.

Like the statements of other governmental and professional organizations, the statements of these organizations emphasize the importance of content knowledge. In addition, they emphasize the need for well-qualified teachers to develop an understanding of the subject appropriate to the level at which they teach as well as an understanding of how to effectively use that knowledge to create opportunities for learning.

\section{RESEARCH ON MATHEMATICS AND SCIENCE TEACHER QUALITY}

Perspectives on mathematics and science teacher quality can be seen in variables used by researchers to operationalize the teacher quality construct. This section discusses the results of an extensive review of the literature focusing on characteristics researchers have used to operationalize individual teacher quality and measures used to examine relationships to teacher effectiveness. From this review, we have identified six primary characteristics studied frequently as indicators of individual teacher quality including: general ability; experience; pedagogical knowledge; subject knowledge; certification status; and teacher behaviors, practices, and beliefs.

\section{General Ability}

Many studies examining the relationship between teachers' effectiveness and their academic and verbal ability use large-scale data sets that do not distinguish among 
teachers of specific subjects. Several of these studies have generally found a positive relationship between teachers' academic ability and student achievement (Greenwald et al., 1966; Hanushek, 1971; Strauss \& Sawyer, 1986). Of these studies, a few include students' mathematics achievement either as part of a composite achievement score or as a separate achievement indicator. For example, Ehrenberg and Brewer $(1994,1995)$ found that having a teacher who had attended a more selective undergraduate institution was statistically significantly associated with higher gains in the average of high school students' test scores in several areas, including mathematics. However, the relationship between teachers' verbal ability and student achievement varied depending on the teachers' race and the students' race and grade level (Ehrenberg \& Brewer, 1995). Ferguson (1991) found that teachers' performance on a test measuring basic literacy skills explained one fifth to one fourth of the variation in 1st-, 3rd-, 5th-, 7th-, 9th-, and 11thgrade students' reading and mathematics achievement scores across 900 school districts; teachers' test scores were "the most important school input for both math and reading" (p. 475). Ferguson and Ladd (1996) found a positive relationship between average teacher ACT scores and 4th-grade student achievement in reading and mathematics. Although the effects were positive in both areas, the result for reading was statistically significant.

Studies of the relationship between teachers' general and verbal ability and student achievement often do not specifically focus on mathematics and science teacher quality. However, a few studies do use student mathematics performance as an outcome measure and these studies generally point to evidence of a positive relationship between teachers' general and verbal ability and student mathematics achievement. This is consistent with findings of studies of the relationship between teacher ability and student achievement without specific focus on mathematics and science.

\section{Teaching Experience}

Studies generally measure teaching experience in terms of either teachers' total years of teaching or teachers' years of teaching in a given district. A few studies examine the impact of these measures on students' mathematics and science achievement. Ferguson (1991) found a positive significant relationship between years of experience and student achievement in reading and mathematics. In the primary grades, five to nine years and nine or more years of experience showed about equal effects on student test scores; in the secondary grades, teachers having nine or more years of experience showed a stronger effect. Hawkins, Stancavage, and Dossey (1998) found statistically significant associations between teacher experience and students' mathematics achievement. Fourth- and eighth-grade students who were taught mathematics by teachers with more than five years of 
experience had higher mathematics scores than students who were taught by teachers with five or fewer years of experience. Fetler (1999) found teaching experience to be significantly positively related to high school students' mathematics scores. Goldhaber and Brewer (1997b) also found teaching experience to be positively related to high school students' mathematics scores; however, the result was not statistically significant. Rivkin, Hanushek, and Kain (2005) reported that students of beginning teachers perform significantly worse than those of experienced teachers on mathematics achievement tests. In science, Druva and Anderson's (1983) meta-analysis of 65 studies found student outcomes in science positively related to teachers' experience; however, the relationship was not particularly strong.

Other studies examining the impact of teacher experience on student achievement report mixed or no results. Rowan, Correnti, and Miller (2002) found that teacher experience was positively related to student mathematics achievement for a cohort of students in Grades 3 to 6 but not for a group of students in Grades 1 to 3. Ferguson and Ladd (1996) found no significant associations between teachers with five or more years of experience and third-, fourth-, eighth-, or ninth-grade students' mathematics achievement. Hill, Rowan, and Ball (2005) found no relationship between years of teaching and first and third graders' mathematics achievement.

In general, studies examining the relationship between teachers' years of experience and their effectiveness report somewhat mixed results. However more studies report a positive relationship (Ehrenberg \& Brewer, 1995; Ferguson, 1991; Fetler, 1999; Goldhaber \& Brewer, 1997b; Greenwald et al., 1996; Hanushek, 1996). Studies focusing on mathematics teachers and student achievement show similar results, although the results appear more consistent at the secondary level. This review found few studies reporting the relationship between teachers' experience and science achievement.

\section{Pedagogical Knowledge}

Teacher education research often examines measures of teachers' pedagogical knowledge as an indicator of teacher quality. These studies use measures such as degrees in education, educational coursework, and scores on exams measuring professional knowledge. Studies of mathematics and science teachers' pedagogical knowledge have reported positive effects of education training on teachers' knowledge and practices (e.g., see Adams \& Krockover, 1997; Gess-Newsome \& Lederman, 1993; Valli \& Agostinelli, 1993). Studies examining the relationship between degrees in education as a measure of teachers' pedagogical knowledge and student outcomes have been more mixed. Hawkins et al. (1998) found that students of fourth-grade teachers who had a college major in education or mathematics education significantly outperformed students of teachers with a major in 
a field other than education, mathematics education, or mathematics. However, eighth-grade students of teachers who had majored in education did not perform as well as those who had majored in mathematics. Goldhaber and Brewer (2000) found that teachers with education degrees had no impact on high school students' science achievement and had a statistically significant negative impact on high school students' mathematics achievement.

Studies using coursework in education as a measure of teachers' pedagogical knowledge indicate a positive relationship between this training and student achievement, particularly at the secondary level. Druva and Anderson's (1983) meta-analysis indicated small positive correlations (coefficients less than .20) between K-12 student outcomes and teachers' background in science and education courses. Examining characteristics of a subgroup of emergency-certified secondary mathematics and science teachers in the NLES:88 data, Darling-Hammond, Berry, and Thoreson (2001) found that secondary students of emergency-certified teachers who had more education training had significantly higher achievement levels than students of teachers with less training.

\section{Coursework in Subject-Specific Pedagogy}

The impact of courses taken in subject-specific pedagogy (i.e., mathematics education or science education methods courses) has also been examined. Chaney (1995) found that eighth-grade students whose teachers had taken coursework in both advanced mathematics (higher than calculus) and mathematics education had the highest mean standardized scores on NLES:88 mathematics test; students of teachers who had taken neither class of courses had the lowest mean standardized score. Chaney found no relationship between a background in science pedagogy and student achievement. Monk (1994) found that courses in undergraduate mathematics pedagogy contributed more to secondary students' achievement gains than did undergraduate mathematics coursework. In science, the study found coursework in science pedagogy positively related to secondary students' achievement, although these effects were much smaller. At the elementary level, Guarino, Hamilton, Lockwood, and Rathbun (2006) found no statistically significant relationship between kindergartners' achievement gains in mathematics and teachers' coursework in mathematics teaching methods.

Generally, much of the research on teachers' pedagogical knowledge examines the impact of teacher training on the development of teaching-related knowledge and skills. A few studies of mathematics and science teachers' pedagogical knowledge examine the impact of education degrees and coursework on student achievement. These studies indicate a more positive impact of degrees in education at the elementary level. At the secondary level, although there is evidence that education degrees have little or negative impact on student achievement, studies 
indicate that coursework taken in subject-specific pedagogy is positively related to secondary student achievement, particularly in mathematics.

\section{Mathematics and Science Subject Matter Knowledge}

Subject-matter knowledge is another teacher characteristic presumed to be indicative of teacher quality. Reviews of research indicate links between teachers' subject-matter preparation and student achievement, although these results are not always clear (Darling-Hammond, 2000; Darling-Hammond \& Youngs, 2002; Wilson \& Floden, 2003; Wilson et al., 2001). Most results that do show consistent positive links between subject matter knowledge and student achievement appear in the area of mathematics (Wilson \& Floden, 2003). Common variables used to measure teacher subject knowledge include subject-specific degrees and coursework.

\section{Subject-Specific Degrees}

The results of studies examining the relationship between teachers holding subject-specific degrees and student achievement vary although mathematics results are generally positive, particularly at the secondary level (Chaney, 1995; Goldhaber \& Brewer, 1997a, 2000; Rowan, Chiang, \& Miller, 1997). For example, Goldhaber and Brewer (1997a, 1997b) found that teachers' holding bachelor's or master's degrees in mathematics had a statistically significant positive relationship to high school students' mathematics achievement (compared to teachers without advanced degrees or out-of-subject degrees). In science, they found holding a bachelor's degree in science (rather than having no degree or a BA in another subject) to have a statistically positive relationship with student achievement (Goldhaber \& Brewer, 1997a). A later study found similar positive results for teachers' having a mathematics BA or MA on secondary students' mathematics achievement but no significant relationship between a science degree and secondary students' science achievement (Goldhaber \& Brewer, 2000). Further, the studies found negative or little impact of teachers having nonsubject specific degrees on student achievement in mathematics and science. Using NLES:88 data, Rowan et al. (1997) found a positive association between teachers holding a degree in mathematics and Grade 10 students' mathematics achievement, although the effect was small. Chaney found significantly positive associations between teachers' having an undergraduate or graduate degree in mathematics and eighth-grade students' performance on the NELS:88 mathematics exam. In science, the same study found positive associations between eighth-grade students' science achievement and teachers' holding graduate degrees in science. Monk (1994), however, found no impact of a major in mathematics on secondary students' mathematics achievement but did find a significant positive relationship of a science major for junior year students' science achievement. 
At the elementary level, studies generally focus on mathematics and indicate mixed or negative effects of teachers having subject-specific degrees on student achievement (Hawkins et al., 1998; Monk, 1994; Rowan et al., 2002). As previously discussed, Hawkins et al. found eighth-grade students whose teachers had majored in mathematics scored higher on the National Assessment of Educational Progress (NAEP) mathematics assessment. Yet researchers found no difference in mathematics performance between fourth-grade students whose teacher had majored in mathematics and students whose teacher had majored in education. Rowan et al. (2002) found that being taught by a teacher with an advanced degree in mathematics was negatively associated with mathematics achievement for elementary students. The researchers note that very few of the teachers in the sample had subject-matter degrees.

\section{Subject-Specific Coursework}

Other studies measure teachers' subject matter knowledge using undergraduate or graduate coursework. Eisenberg (1977) found no significant relationships between algebra teachers' coursework in advanced mathematics, collegiate mathematics grade point average, scores on an algebra test, and student achievement. Chaney (1995), however, found that a background in advanced mathematics courses predicted eighth-grade student achievement in mathematics after controlling for teaching assignments. In science, teachers' subject area grade point average and having taken more than 40 credits in earth and physical sciences predicted student achievement. Druva and Anderson (1983) found student achievement to be positively related to the number of biology courses taken (for biology teachers) and the number of science course taken, in general. Monk (1994) found that the effects of teacher content preparation appeared to vary for different groups of students. For example, the number of mathematics courses in a teacher's background had a positive effect on students enrolled in advanced mathematics courses but no effect on students enrolled in remedial courses. Although the data suggested a positive relationship between coursework and students' mathematics achievement, there was evidence of a curvilinear effect in which the positive effect of a teacher's undergraduate subject coursework on student achievement diminished after five courses (Monk, 1994). In science, the effects of subject matter coursework were dependent upon the area of science studied (i.e., physical, earth, or life sciences). For example, Monk and King (1994) found that coursework in the life sciences had no impact on student achievement, but coursework in the physical sciences had a positive impact on higher ability students during the sophomore year. At the elementary level, Eberts and Stone (1984) found the number of college-level mathematics courses teachers had taken in the last three years was not significantly related to fourth-grade students' mathematics achievement gains. 


\section{Subject-Specific Knowledge for Teaching}

In the past two decades, researchers in teacher education have examined the nature of the knowledge needed for teaching and the role of this knowledge in teacher quality. This discussion stems from a perspective that knowing a subject for oneself is not adequate to effectively carry out the work of teaching. Rather, teachers must have an understanding of content as well as knowledge of how students think and understand the content. In other words, teachers use subjectspecific content in their work differently from the way others might use content in nonteaching professions. Shulman (1986) introduced pedagogical content knowledge, knowledge "which goes beyond knowledge of subject matter per se to the dimension of subject matter knowledge for teaching" (p. 9). This knowledge includes ways of representing a topic in a way that makes is accessible to learners and understanding what facilitates or hinders learning of a topic. Other work in the area of subject knowledge for teaching has proposed various organizational structures for and theories of teacher knowledge (Ball, 1991; Ball \& Bass, 2000; Grossman, 1990; Leinhardt \& Smith, 1985; Ma, 1999). Much of this theoretical work has occurred in the area of mathematics. For example, Ma described profound understanding of fundamental mathematics, in her comparison of the nature of the subject matter knowledge of U.S. and Chinese elementary teachers. Such knowledge includes connections among topics and knowledge of multiple representations and explanations of topics. Ball $(1991,2003)$ described mathematical knowledge for teaching, which argues that teachers must not only know the subject matter for themselves but also understand the subject in a way that enables them to effectively use in it instruction.

Research in this area has focused on examinations and comparisons of preservice and expert teachers' content knowledge for teaching (Ball, 1990; Leinhardt \& Smith, 1985; Simmons et al., 1999; Stacey et al., 2001), changes in preservice and inservice teachers knowledge through participation in methods courses and professional development experiences (Borko et al., 1992; Davis \& Krajcik, 2005; Kinach, 2002; Smith, 2000), international comparisons of teachers' knowledge (An, Kulm, \& Wu, 2004; Ma, 1999) and how teachers' content knowledge for teaching might influence their instructional decisions and practices (McDuffie, 2004; Thompson \& Thompson, 1996). Research on the relationship between teachers' knowledge for teaching and student achievement has been limited and generally in the area of mathematics. Carpenter, Fennema, Perterson, and Carey (1988) examined relationships between teachers' pedagogical content knowledge and elementary student achievement. The researchers used instruments designed to measure 40 first-grade teachers knowledge of children's solutions of addition and subtraction problems including distinctions among problem types, knowledge of children's strategies, and knowledge of their own students. They found teachers' ability to predict whether their own students could solve different problems was 
significantly correlated with their students' achievement in number facts and problem solving. Hill, Schilling, and Ball (2004) developed measures for the purpose of determining growth in teachers' mathematical knowledge for teaching. The researchers argue that up to this point, "scholars have not attempted to measure teachers' knowledge for teaching in a rigorous manner and thus cannot track its development or contribution to student achievement" (p. 14). Hill et al. (2005) used their measures to examine relationships between teachers' mathematical knowledge for teaching and first- and third-grade students' gains in mathematics. They found that teachers' knowledge was significantly related to student achievement gains in both grades.

Although the research is not definitive, studies indicate a trend toward a positive relationship between secondary teachers' subject knowledge and student achievement, particularly in mathematics. Secondary teachers who hold a bachelor's or master's degrees in mathematics appear to have positive impacts on student achievement. Results for science are similar, although not as strong. Teacher coursework in mathematics and science also appears to have a positive impact on student achievement, although at least one study found the impact diminishes after a particular number of courses and differs depending upon the level of course (remedial vs. advanced) in mathematics and the area of study (e.g., physical vs. life sciences) in science. At the elementary level, the impact of teachers' subjectspecific degrees and coursework is unclear. However, the development of new measures of elementary teachers' mathematical knowledge for teaching holds promise of providing additional information on the relationship between teachers' knowledge and student achievement.

\section{Mathematics and Science Teacher Certification Status and Certification Routes}

Teacher certification status is frequently used as a measure of the effects of knowledge gained from teacher preparation (Darling-Hammond, 2000; DarlingHammond \& Youngs, 2002). Comparisons are often made between those who are fully certified and those who hold provisional or emergency certification; several studies indicate an advantage in favor of fully certified teachers on measures of student achievement and teacher performance evaluations (Darling-Hammond, 2000; Fetler, 1999). Darling-Hammond (2000), using data from the 1993-94 School and Staffing Survey found a state's percentage of fully certified teachers (full certification and a major in their field) to be significantly and positively related to average NAEP mathematics scores in Grades 4 and 8. Mathematics achievement was negatively related to the percentage of all teachers less than fully certified, the percentage of all uncertified teachers new to the field, and the percentage of all uncertified new hires. Goldhaber and Brewer (2000) found that high school students of mathematics teachers with private school or no certification 
did significantly worse on mathematics tests than students of teachers with infield standard or emergency certification. Results for science were similar but not as strong. Guarino et al. (2006) found no statistically significant relationship between teachers' certification and kindergarteners' achievement gains in mathematics.

Several studies focusing on mathematics and science teaching and student achievement explore the impact of subject-specific certification. Hawk, Coble, and Swanson (1985) found that students in Grades 6 to 12 having teachers fully certified in mathematics scored significantly higher on achievement tests than students with out-of-field teachers, particularly in algebra. Goldhaber and Brewer (1997b) found a significant negative relationship between student achievement and certification (not subject specific) and a significant positive association between students' mathematics achievement and teachers' certification in mathematics.

Research also examines differences in the quality of regularly versus alternatively certified teachers, usually in terms of teacher outcomes such as subject area and professional knowledge tests, performance ratings, and teacher observations. Few studies were found examining associations between regularly and alternatively certified teachers and student outcomes. These are in the area of mathematics. Laczko-Kerr and Berliner (2002) compared Grades 3 to 8 students' SAT 9 reading, mathematics, and language arts scores (in 1998 and 1999) of matched pairs of certified and undercertified teachers, including teachers from Teach for America, a popular alternative certification program. Results indicated that students of certified teachers scored significantly higher in mathematics on the 1999 results. Results in 1998 were also positive but not significant. Further analysis within the group of undercertified teachers indicated that Teach for America teachers did not perform significantly differently than other undercertified teachers. Darling-Hammond, Holtzman, Gatlin, and Heilig (2005) found similar results.

Results of studies examining the relationship between teacher certification and student outcomes are often viewed as inconclusive because of wide variations in the scope and quality of such programs. However, studies using more targeted measures, such as subject-specific certification, report a positive relationship between certification status and student achievement, particularly in mathematics at the secondary level. The results for secondary science show similar trends but are generally weaker. There are fewer studies on the impact of subject-specific certification at the elementary level.

\section{Mathematics and Science Teacher Behaviors, Practices, and Beliefs}

Teacher behaviors, instructional practices, and beliefs are also examined as indicators of teacher quality. Much of the research on the relationship between teachers' behaviors, practices, and beliefs and student outcomes occurs in mathematics. Peterson, Fennema, Carpenter, and Loef (1989) found a significant relationship 
between first-grade teachers' pedagogical content beliefs about addition and subtraction and student achievement. Students of teachers who held a more cognitively based perspective (i.e., teachers who believe children construct their own knowledge, skills should be taught in relation to understanding, and mathematics instruction should build on students' prior knowledge and understanding) scored significantly higher on problem solving measures than students of teachers who held less cognitively based perspectives. A study examining teachers' pedagogical beliefs and elementary students' mathematics achievement found that students of teachers who held more constructivist beliefs did better on word problem tests than students whose teachers used a more direct-instruction approach (Staub \& Stern, 2002). Carter and Norwood (1997) found a significant relationship between the alignment of fourth- and fifth-grade teachers' beliefs about mathematics to NCTM's Principles and Standards for School Mathematics and students' beliefs that working hard to solve challenging problems and understand concepts would lead to success. Stipek, Givven, Salmon, and MacGyvers (2001) found that fourththrough sixth-grade teachers' self-confidence as teachers of mathematics was significantly related to students' self-confidence as learners. Love and Kruger (2005) examined the relationship between teachers' beliefs and student achievement in urban elementary schools serving African American children. Results found a significant positive correlation between teacher beliefs that all children can be successful and students' achievement in mathematics.

Other studies examine relationships between mathematics teachers' practices and student outcomes. Analysis of data from the Early Childhood Longitudinal Study, Kindergarten Class of 1998-99, found instructional practices of kindergarten teachers to be significantly associated with student gains in mathematics (Guarino et al., 2006). These include spending more time on the subject; using traditional instructional approaches; emphasizing computation; working on advanced numeracy, measurement, and other concepts; and the use of student-centered instruction techniques. Turner, Meyer, Midgley, and Patrick (2003) compared the relationship between differences in teachers' discourse and students' motivation in two sixth-grade classrooms. Students in the class with a higher occurrence of teacher discourse that encouraged student autonomy and fostered intrinsic motivation reported fewer instances of avoidance behavior or negative affect in the face of difficulties.

Research examining the relationship between teachers' use of instructional practices aligned with the NCTM Standards and reform-based curricula has found positive results. Sowell (1989) found positive relationships between the use of manipulative materials and K-16 student achievement. Stipek et al. (1998) found a positive relationship between teachers' instructional practices such as a focus on learning and understanding and fostering positive emotions toward mathematics learning and fourth- through sixth-grade students' achievement. Hiebert (1999), in a review of research, found a positive relationship between instructional 
approaches that emphasize conceptual development of primary grades arithmetic and students' conceptual understanding of the topic. Ginsburg-Block and Fantuzzo (1998) found the use of problem solving and peer collaboration with low-achieving third and fourth graders positively associated with achievement in computation and word problem tasks. Cohen and Hill (2000) report a small positive relationship between California teachers' reported use of practices aligned with state mathematics reform and fourth-grade student achievement. Wenglinsky $(2002,2004)$ found instruction emphasizing higher order thinking, the use of hands-on learning, and solving problems with multiple solutions positively associated with fourth- and eighth-grade students' achievement on the mathematics NAEP. Hamilton et al. (2003) examined relationships between teachers' reported use of standards-based instruction (i.e., practices that support active learning, promote higher order thinking, and connect learning to real-world contexts) and student achievement in $11 \mathrm{~K}-8$ schools. Although results indicated small, positive relationships to student achievement in mathematics, there were similar but not significant trends in science.

At the high school level, Mayer (1989) examined differences in achievement of middle and high school algebra students taught in classrooms using instructional practices aligned with the NCTM Standards and students in classrooms using more traditional approaches. Results indicated that students of teachers reporting greater use of standards-based practices had higher achievement growth than students of teachers reporting lower use of such practices. This was particularly true for higher ability students. An examination of high school classrooms using a standards-based curriculum found that teacher practices aligned with the goals of the curriculum (i.e., collaborative planning among teachers, collaborative work among students, use of multiple assessment methods, and emphasis on high expectations) were significantly related to growth in student achievement (Schoen, Cebulla, Finn, \& Fi, 2003).

In science, research has examined the relationship between instructional practices that engage students in developing models, explaining and justifying claims, designing and conducting inquiries, and making use of meaningful problems and student outcomes (Committee on Science Learning, 2007). Kolodner et al. (2003) found the use of project-based inquiry approaches to have a positive impact on middle school students' learning. Students in the project-based class performed significantly better than students in the traditional class on collaborative, metacognitive, and science skills (e.g., designing tests and explaining and justifying claims). Rivet and Krajcik (2004) found that students in classrooms using project-based instruction showed large, significant gains in science content and process skills. Marx et al. (2004) found similar results for students in Grades 6, 7, and 8. Analysis of data from the National Educational Longitudinal Study found the use of hands-on laboratories positively related to 10th-grade students' science achievement (Burkam, Lee, \& Smerdon, 1997). An examination of the 
use of inquiry-based teaching practices found significant relationships between the use of these strategies and secondary students' science achievement (Von Secker, 2002). Teacher practices included encouraging students' interest in science, engaging students in laboratory and problem solving tasks, promoting students' further study of topics, and using scientific writing.

The research indicates that what mathematics and science teachers believe about teaching and learning and what they do in their classrooms have an impact on student outcomes. Much of the research uncovered for our review focused on the use of reform- or standards-based practices in mathematics instruction at the K-8 level. This research indicates positive results on student achievement. Studies focusing on mathematics at the secondary level indicate similar results. In science, studies indicate evidence of a positive relationship between the use of hands-on activities and practices related to inquiry-based instruction.

\section{DISCUSSION}

The quality of mathematics and science teaching has been the focus of much attention in recent years as the United States faces the challenge of maintaining its competitiveness in an increasingly global economy (National Academies, 2006). International comparisons, such as the Trends in International Mathematics and Science studies, have indicated that U.S. students lag behind their peers in other countries in mathematics and science (Hiebert et al., 2003). As a result, the interest in identifying characteristics that determine quality in mathematics and science teachers has grown. The teacher quality research reviewed here, with a focus on mathematics and science, provides some insight into the relationships between teacher characteristics and student outcomes.

\section{What Do We Know About Mathematics and Science Teacher Quality?}

This article indicates trends toward positive relationships between subject matter preparation (as measured by subject-specific degrees and coursework) and student achievement, particularly in secondary mathematics. Although the impact of nonspecific degrees on secondary student achievement in mathematics and science has been inconclusive, evidence points to the generally positive impact of subjectspecific degrees on secondary students' mathematics achievement (Chaney, 1995; Goldhaber \& Brewer, 1997a, 1997b, 2000). In science, the research indicates that the relationship between science teachers' subject matter preparation and student achievement depends upon the area of science (e.g., physical science, life science, earth science, etc.). Although the relationship in science is less clear, there remains evidence of a positive trend. These results align with the emphasis on subject-matter preparation evident in the NCLB Act and related policy documents. 
Although the evidence supports the idea that mathematics and science teachers must know their subject, there are indications that preparation in pedagogy is also beneficial. In mathematics, there is evidence of a positive relationship between subject-specific certification (which often includes both work in content and pedagogy) and student achievement at the secondary level (Goldhaber \& Brewer, 1997b; Hawk et al., 1985). Evidence of positive associations (for secondary mathematics and, to a lesser degree, science) to coursework in subject-specific methods also supports this view. This conclusion closely aligns with recommendations by leading professional organizations such as the Council of Scientific Society Presidents, the NCTM, and NSTA, described previously, as well as other recent recommendations that advocate a closer link between mathematics content and pedagogy in the preparation of teachers (Conference Board of the Mathematical Sciences, 2001; Ferrini-Mundy \& Findell, 2001).

Although the findings regarding mathematics and science subject matter preparation are generally positive at the secondary level, the impact of such preparation on the effectiveness of elementary teachers is inconclusive. Studies that examine the effect of subject-specific degrees and certification at the elementary level have noted the small number of teachers in the population who possess such credentials (Rowan et al., 2002); rather, elementary teachers are usually generalists and their credentials reflect this status. However, the focus on improving the quality of mathematics and science teaching and learning extends to K-12 and beyond. Therefore there is interest in determining what impact subject matter preparation might have on elementary teachers' effectiveness. Because subject-specific degrees and certification are not adequate measures for this teacher population, alternative measures are needed to determine how much and what type of subjectspecific knowledge might be important. Ball (2003) argued that requiring teachers to study more mathematics is helpful only if teachers are learning the mathematics in ways that will help them help their students learn more mathematics. Research using instruments designed to measure mathematical knowledge used in teaching indicates that elementary teachers' performance on these measures are positively associated with student achievement in mathematics (Hill et al., 2005). Additional research using these and similar measures will further illuminate this issue.

\section{What Further Research on Mathematics and Science Teacher Quality Can Offer}

Similar to reviews of research on general teacher quality (Wilson et al., 2001), the review of research on mathematics and science teacher quality and its relationship to student outcomes highlights the need for more targeted measures. For example, researchers need more information about the relationship between specific experiences and courses in mathematics and science teacher preparation and teacher quality in terms of student outcomes. What are the specific components of quality 
mathematics and science teacher certification programs (whether traditional or alternative) that are positively related to student outcomes? What is the form and content of subject knowledge that most contributes to student learning? These questions would benefit from further exploration.

In addition, this review found fewer studies examining relationships between characteristics of teachers and student outcomes in the area of science than in mathematics. Those studies that examined relationships in both areas (Chaney, 1995; Goldhaber \& Brewer, 1997a, 2000; Monk, 1994) often found more mixed results. One reason for this could be that the measures need to be refined to examine specific areas of science (e.g., physical, life, earth, and space sciences). For example, although examinations of subject-specific certification looked at secondary teachers' certification in science, they did not separate these into specific areas of certification and achievement such as biology, chemistry, or physics. Perhaps refining these measures to reflect topics in science education would yield more straightforward results. Because of the documented shortage of certified mathematics and science teachers (Ingersoll, 2001), these issues are becoming increasingly important.

More targeted measures will also give greater insights into the specific contributions of teacher characteristics that already appear to be important indicators of teacher quality. As seen in the example of degrees and certification, using measures of subject-specific degrees and certification provides more insight on the impact of these characteristics. Yet a mathematics degree from one institution is not the same as it is from another; similar variations exist in certification requirements across states. Further, as discussed earlier, the use of subject-specific degrees and certification may not be practical for some populations of teachers. Researchers need similar measures of teacher knowledge that can be used across several studies (Floden \& Meniketti, 2005). This would provide more precise information on the impact of specific types of teacher knowledge on student outcomes and allow schools of education and other preparers of teachers to be more focused and targeted in the development and delivery of their programs. The shortage in qualified mathematics and science teachers must be addressed, and the development of alternative paths to certification is one response to this issue. As a result, there will continue to be an increase in the variety of available routes to becoming a teacher. Thus it is more important than ever to understand exactly what characteristics define a qualified mathematics and science teacher and how best to prepare an individual to fill that role.

\section{CONCLUSION}

This article was developed to provide various audiences with an overview of the research on the relationships between individual characteristics of mathematics and science teachers and student outcomes. This is in no way an exhaustive 
review of the entire body of literature on teacher quality. There exists much other research about relationships between the variables explored in this review and teacher outcomes (e.g., changes and influences on teacher beliefs, practices, and organization of knowledge), the effects of interventions designed to influence teacher quality (e.g., professional development experiences), and contextual issues in teaching and learning (e.g., school setting and student diversity). Although it was beyond the scope of this review to examine all of these areas, this broad synthesis of mathematics and science teacher quality as it relates to student outcomes is one resource for policymakers, educators, and researchers as they consider the complex issue of teacher quality in mathematics and science.

\section{ACKNOWLEDGMENT}

This study is one in a series of substudies for the Math and Science Partnership Program Evaluation (MSP-PE) conducted for the National Science Foundation's MSP Program. The MSP-PE is conducted under Contract No. EHR-0456995. Since 2007, Bernice Anderson, Ed.D., Senior Advisor for Evaluation, Directorate for Education and Human Resources, has served as the National Science Foundation Program Officer. The authors, are Johnna J. Bolyard, from West Virgina University, and Patricia S. Moyer-Packenham, Utah State University (formerly of George Mason University).

The MSP-PE is led by COSMOS Corporation in current partnership with George Mason University (GMU) and Brown University. Robert K. Yin (COSMOS) serves as Principal Investigator and Jennifer Scherer (COSMOS) serves as one of three Co-Principal Investigators. Additional Co-Principal Investigators and their collaborating institutions (including discipline departments and math centers) are Patricia Moyer-Packenham (USU, formerly GMU) and Kenneth Wong (Brown).

\section{REFERENCES}

Adams, P. E., \& Krockover, G. H. (1997). Beginning science teacher cognition and its origins in the preservice secondary science teacher program. Journal of Research in Science Teaching, 34, 633-653.

An, S., Kulm, G., \& Wu, Z. (2004). The pedagogical content knowledge of middle school mathematics teachers in China and the U.S. Journal of Mathematics Teacher Education, 7, 145-172.

Association for Science Teacher Education. (2004). ASTE Position Statement Science Teacher Preparation and Career-long Development. Retrieved February 22, 2007, from http://aste.chem.pitt.edu/

Ball, D. L. (1990). Prospective elementary and secondary teachers' understanding of division. Journal of Research in Mathematics Education, 21, 132-144.

Ball, D. L. (1991). Research on teaching mathematics: Making subject matter knowledge part of the equation. In J. Brophy (Ed.), Advances in research on teaching (Vol. 2, pp. 1-41). Greenwich, CT: JAI Press. 
Ball, D. L. (2003). What mathematical knowledge is needed for teaching mathemat$i c s$ ? Retrieved February 10, 2005, from the U.S. Department of Education Web site: http://www.ed.gov/inits/mathscience/ball.html

Ball, D. L., \& Bass, H. (2000). Interweaving content and pedagogy in teaching and learning to teach: Knowing and using mathematics. In J. Boaler (Ed.), Multiple perspectives on the teaching and learning of mathematics (pp. 83-104). Westport, CT: Ablex.

Blank, R. K., \& Langeson, D. (1999). State indicators of science and mathematics education 1999: State-by-state trends and new indicators from the 1997-98 school year. Washington, DC: Council of Chief State School Officers.

Boote, D. N., \& Beile, P. (2005). Scholars before researchers: On the centrality of the dissertation literature review in research preparation. Educational Researcher, 34(6), 3-15.

Borko, H., Eisenhart, M., Brown, C. A., Underhill, R. G., Jones, D., \& Agard, P. C. (1992). Learning to teach hard mathematics: Do novice teachers and their instructors give up too easily? Journal for Research in Mathematics Education, 23, 194-222.

Burkam, D. T., Lee, V. E., \& Smerdon, B. A. (1997). Bender and science learning in early high school: Subject matter and laboratory experiences. American Educational Research Journal, 34, 297-331.

Carpenter, T. P., Fennema, E., Peterson, P. L., \& Carey, D. A. (1988). Teachers' pedagogical content knowledge of students' problem solving in elementary arithmetic. Journal for Research in Mathematics Education, 19, 385-401.

Carter, G., \& Norwood, K. S. (1997). The relationship between teacher and student beliefs about mathematics. School Science and Mathematics, 97, 62-67.

Chaney, B. (1995) Student outcomes and the professional preparation of eighth-grade teachers in science and mathematics. Arlington, VA: National Science Foundation. (ERIC Document Reproduction Service No. ED 389530)

Cochran-Smith, M. \& Zeichner, K. M. (Eds.). (2005). Studying teacher education: The report of the AERA panel on research and teacher education. Mahwah, NJ: Erlbaum.

Cohen, D. K., \& Hill, H. (2000). Instructional policy and classroom performance: The mathematics reform in California. Teachers College Record, 102, 294-344.

Committee on Science Learning, Kindergarten through Eighth Grade. (2007). Taking science to school: Learning and teaching science in grades $K-8$ (R. A. Duschl, H. A. Schweingruber, \& A. W. Shouse, Eds.). Washington, DC: National Academies. Retrieved February 28, 2007, from http://books.nap.edu/openbook.php?record_id=11625\&page $=$ R1

Conference Board of the Mathematical Sciences. (2001). The Mathematical Education of TeachersIssues on Mathematics Education (Vol. 11). Providence, RI: American Mathematical Society. Retrieved February 22, 2007, from the Conference Board of the Mathematical Sciences Web site: http://www.cbmsweb.org/MET_Document/index.html

Council of Scientific Society Presidents. (2004). The need for well-qualified science and math teachers. Retrieved March 5, 2006, from the Council of Scientific Society Presidents Web site: http://www.nctm.org/news/2004_12_cssp_position.pdf

Darling-Hammond, L. (2000). Teacher quality and student achievement: A review of state policy evidence. Educational Policy Analysis Archives, 8(1). Retrieved February 2005 from http://epaa.asu.edu/epaa/v8n1

Darling-Hammond, L., Berry, B., \& Thoreson, A. (2001). Does teacher certification matter? Evaluating the evidence. Educational Evaluation and Policy Analysis, 23, 57-77.

Darling-Hammond, L., Holtzman, D. J., Gatlin, S. J., \& Heilig, J. V. (2005). Does Teacher Preparation Matter? Evidence about Teacher Certification, Teach for America, and Teacher Effectiveness. Retrieved August 16, 2005, from Stanford University, Center for Teacher Education and School Reform Web site: http://schoolredesign.net/srn/news/certification.html

Darling-Hammond, L., \& Youngs, P. (2002). Defining "highly qualified teachers": What does "scientifically-based research" actually tell us? Educational Researcher, 31(9), 13-25. 
Davis, E. A., \& Krajcik, J. S. (2005). Designing educative curriculum materials to promote teacher learning. Educational Researcher, 34(3), 3-14.

Druva, C. A., \& Anderson, R. D. (1983). Science teacher characteristics by teacher behavior and by student outcome: A meta-analysis of research. Journal of Research in Science Teaching, 20, 467-479.

Eberts, R. W., \& Stone, J. A. (1984). Unions and public schools. Lexington, MA: D. C. Heath.

Ehrenberg, R. G., \& Brewer, D. J. (1994). Do school and teacher characteristics matter? Evidence from high school and beyond. Economics of Education Review, 13(1), 1-17.

Ehrenberg, R. G., \& Brewer, D. J. (1995). Did teachers' verbal ability and race matter in the 1960s? Coleman revisited. Economics of Education Review, 14(1), 1-21.

Eisenberg, T. A. (1977). Begle revisited: Teacher knowledge and student achievement in algebra. Journal for Research in Mathematics Education, 8, 216-222.

Ferguson, R. F. (1991). Paying for public education: New evidence on how and why money matters. Harvard Journal on Legislation, 28, 465-498.

Ferguson, R. F. \& Ladd, H. F. (1996). How and why money matters: An analysis of Alabama schools. In H. F. Ladd (Ed.), Holding schools accountable: Performance-based reform in education (pp. 265-298). Washington, DC: Brookings Institution.

Ferrini-Mundy, J., \& Findell, B. (2001). The mathematical education of prospective teachers of secondary school mathematics: Old assumptions, new challenges. In CUPM discussion papers about mathematics and the mathematical sciences in 2010: What should students know? (pp. 31-41). Washington, DC: Mathematical Association of America.

Fetler, M. (1999). High school staff characteristics and mathematics test results. Education Policy Analysis Archives, 7(9). Retrieved from http://epaa.asu.edu/epaa/v7n9

Floden, R., \& Meniketti, M. (2005). Research on the effects of coursework in the arts and sciences and in the foundations of education. In M. Cochran-Smith \& K. M. Zeicher (Eds.), Studying teacher education: The report of the AERA panel on research and teacher education. (pp. 261-308) Mahwah, NJ: Erlbaum.

Gess-Newsome, J., \& Lederman, N. G. (1993). Preservice biology teachers' knowledge structures as a function of professional teacher education: A yearlong assessment. Science Education, 77, 25-45.

Ginsberg-Block, M. B., \& Fantuzzo, J. W. (1998). An evaluation of the relative effectiveness of NSTM standards-based interventions for low-achieving urban elementary students. Journal of Educational Psychology, 90, 560-569.

Goldhaber, D. D., \& Brewer, D. J. (1997a). Evaluating the effect of teacher degree level on educational performance. In W. J. Fowler (Ed.), Developments in school finance, 1996 (pp. 197-210). Washington, DC: National Center for Education Statistics, U.S. Department of Education.

Goldhaber, D. D., \& Brewer, D. J. (1997b). Why don't schools and teachers seem to matter? Assessing the impact of unobservables on educational productivity. The Journal of Human Resources, 32, 505-523. Retrieved May 25, 2005, from JSTOR database.

Goldhaber, D. D., \& Brewer, D. J. (2000). Does teacher certification matter? High school teacher certification status and student achievement. Educational Evaluation and Policy Analysis, 22(2), $129-146$.

Greenwald, R., Hedges, L. V., \& Laine, R. D. (1996). The effect of school resources on student achievement. Review of Educational Research, 66, 361-396.

Grossman, P. L. (1990). The making of a teacher: Teacher knowledge and teacher education. New York: Teachers College Press.

Guarino, C. M., Hamilton, L. S., Lockwood, J. R., \& Rathbun, A. H. (2006). Teacher qualifications, instructional practices, and reading and mathematics gains of kindergartners (Report No. NCES 2006-031). Washington, DC: National Center for Education Statistics. (ERIC Document Reproduction Service No. ED491190) 
Hamilton, L. S., McCafrey, D. F., Stecher, B. M., Klein, S. P., Robyn, A., \& Bugliari, D. (2003). Studying large-scale reforms of instructional practice: An example form mathematics and science. Educational Evaluation and Policy Analysis, 25, 1-29.

Hanushek, E. (1971). Teacher characteristics and gains in student achievement: Estimation using micro data. The American Economic Review, 61, 280-288.

Hanushek, E. (1996). A more complete picture of school resource policies. Review of Educational Research, 66, 397-409.

Hawk, P. P., Coble, C. R., \& Swanson, M. (1985). Certification: It does matter. Journal of Teacher Education, 36(3), 13-15.

Hawkins, E. F., Stancavage, F. B., \& Dossey, J. A. (1998). School policies and practices affecting instruction in mathematics: Findings from the National Assessment of Educational Progress. Washington, DC: U.S. Department of Education, Office of Educational Research and Improvement. (ERIC Document Reproduction Service No. ED 424116)

Hiebert, J. (1999). Relationships between research and the NCTM standards. Journal for Research in Mathematics Education, 30, 3-19.

Hiebert, J., Gallimore, R., Garnier, H., Givvin, K. B., Hollingsworth, H., Jacobs, J., et al. (2003). Teaching Mathematics in Seven Countries: Results from the TIMSS 1999 Video Study (No. NCES 2003-013 Revised). Washington DC: U.S. Department of Education, National Center for Education Statistics.

Hill, H. C., Rowan, B., \& Ball, D. L. (2005). Effects of teachers' mathematical knowledge for teaching on student achievement. American Educational Research Journal, 42, 371-406.

Hill, H. C., Schilling, S. G., \& Ball, D. L. (2004). Developing measures of teachers' mathematics knowledge for teaching. The Elementary School Journal, 105, 11-30.

Ingersoll, R. M. (2001). Teacher turnover, teacher shortages, and the organization of schools: A CTP working paper. Seattle: Center for the Study of Teaching and Policy. Retrieved February 28, 2007, from http://depts.washington.edu/ctpmail/PDFs/Turnover-Ing-01-2001.pdf

Kinach, B. M. (2002). A cognitive strategy for developing pedagogical content knowledge in the secondary mathematics methods course: Toward a model of effective practice. Teaching and Teacher Education, 18, 51-71.

Kolodner, J. L., Camp, P. J., Crismond, D., Fasse, B., Gray, J., \& Holbrook, J. (2003). Problem-based learning meets case-based reasoning in the middle-school science classroom: Putting learning by design into practice. The Journal of the Learning Sciences, 12, 495-547.

Laczko-Kerr, I., \& Berliner, D. C. (2002). The effectiveness of "Teach for America" and other undercertified teachers on student academic achievement: A case of harmful public policy. Educational Policy Analysis Archives, 10(37). Retrieved March 4, 2005, from http://epaa.asu.edu/epaa/v10n37/

Leinhardt, G., \& Smith, D. A. (1985). Expertise in mathematics instruction: Subject matter knowledge. Journal of Educational Psychology, 77, 247-271.

Leitzel, J. R. C. (Ed.). (1991). A call for change: Recommendations for the mathematical preparation of teachers. Washington, DC: Mathematical Association of America.

Love, A., \& Kruger, A. C. (2005). Teacher beliefs and student achievement in urban schools serving African American students. Journal of Educational Research, 99, 87-98.

Ma, L. (1999). Knowing and teaching elementary mathematics: Teachers' understanding of fundamental mathematics in China and the United States. Mahwah, NJ: Erlbaum.

Marx, R. W., Blumenfeld, P. C., Krajcik, J. S., Fishman, B., Soloway, E., Geier, R., et al. (2004). Inquiry-based science in the middle grades: Assessment of learning in urban systemic reform. Journal of Research in Science Teaching, 41, 1063-1080.

Mayer, D. P. (1989). Do new teaching standards undermine performance on old tests? Educational Evaluation and Policy Analysis, 20, 53-73.

McDuffie, A. R. (2004). Mathematics teaching as a deliberate practice: An investigation of elementary pre-service teachers' reflective thinking during student teaching. Journal of Mathematics Teacher Education, 7, 33-61. 
Mitchell, K. J., Robinson, D. Z., Plake, B. S., \& Knowles, K. T. (2001). Testing teacher candidates: The role of licensure tests in improving teacher quality. Washington, DC: National Academy Press. Monk, D. H. (1994). Subject area preparation of secondary mathematics and science teachers and student achievement. Economics of Education Review, 13(2), 125-145.

Monk, D. H., \& King, J. A. (1994). Multilevel teacher resource effects in pupil performance in secondary mathematics and science: The case of teacher subject matter preparation. In R. G. Ehrenberg (Ed.), Choices and consequences: Contemporary policy issues in education (pp. 29-58). Ithaca, NY: ILR Press.

National Academies. (2006). Rising above the gathering storm: Energizing and employing America for a brighter economic future. Washington, DC: Author. Retrieved October 13, 2006 from the National Academies Web site: http://books.nap.edu/openbook.php?record_id=11463\&page=R3

National Board for Professional Teaching Standards. (2002). What teachers should know and be able to do. Retrieved October 16, 2006, from http://www.nbpts.org/UserFiles/File/what_teachers.pdf

National Commission on Mathematics and Science Teaching for the 21st Century. (2000). Before it's too late: A report to the nation from the national commission on mathematics and science teaching for the 21 st century. Washington, DC: U.S. Department of Education. Retrieved February 20, 2007, from http://www.ed.gov/inits/Math/glenn/report.pdf

National Commission on Teaching and America's Future. (1996). What matters most: Teaching for America's future. Retrieved July 8, 2006, from http://www.nctaf.org/documents/ WhatMattersMost.pdf

National Council of Teachers of Mathematics. (1991). Professional standards for teaching mathematics. Reston, VA: Author.

National Council of Teachers of Mathematics. (2005). Highly qualified teachers. Retrieved April 25, 2006, from http://www.nctm.org/about/position_statements/qualified.htm

National Research Council. (1996). National science standards. Retrieved February 22, 2007, from the National Academies Web site: http://books.nap.edu/readingroom/books/nses/4.html

National Science Teachers Association. (2004). Science teacher preparation. Retrieved October 10, 2006, from http://www.nsta.org/positionstatement\&psid=42

Office of the U.S. Press Secretary. (2006, April 18). Fact sheet: The American competitiveness initiative (Press release). Washington, DC: Author. Retrieved February 21, 2007, from http://www.whithouse.gov/news/releases/2006/04/20060418-8.html

Peterson, P. L., Fennema, E., Carpenter, T. P., \& Loef, M. (1989). Teachers' pedagogical content beliefs in mathematics. Cognition and Instruction, 6, 1-40.

Rice, J. K. (2003). Teacher quality: Understanding the effectiveness of teacher attributes. Washington, DC: Economic Policy Institute.

Rivet, A., \& Krajcik, J. S. (2004). Achieving standards in urban systemic reform: An example of a sixth grade project-based science curriculum. Journal of Research in Science Teaching, 41, 669-692.

Rivkin, S. G, Hanushek, E. A., \& Kain, J. F. (2005). Teachers, schools, and academic achievement. Econometrica, 73, 417-458.

Rowan, B., Chiang, F., \& Miller, R. J. (1997). Using research on employees' performance to the study effects of teachers on students' achievement. Sociology of Education, 70(4), 256-284.

Rowan, B., Correnti, R., \& Miller, R. J. (2002). What large-scale, survey research tells us about teacher effects on student achievement: Insights from the Prospects study of elementary schools. Teachers College Record, 104, 1525-1567.

Sanders, W. L., \& Rivers, J. C. (1996). Cumulative and residual effects of teachers on future academic achievement. Knoxville: University of Tennessee Value-Added Research and Assessment Center.

Schoen, H. L., Cebulla, K. J., Finn, K. F., \& Fi, C. (2003). Teacher variables that relate to students achievement when using a standards-based curriculum. Journal for Research in Mathematics Education, 34, 228-243. 
Shulman, L. S. (1986). Those who understand: Knowledge growth in teaching. Educational Researcher, 15(2), 4-14.

Simmons, P. E., Emory, A., Carter, T., Coker, T., Finnegan, B., Crockett, D., et al. (1999). Beginning teachers: Beliefs and classroom actions. Journal of Research in Science Teaching, 36, 930-954.

Smith, D. C. (2000). Content and pedagogical content knowledge for elementary science teacher educators: Knowing our students. Journal of Science Teacher Education, 11, 27-46.

Sowell, E. J. (1989). Effects of manipulative materials in mathematics instruction. Journal for Research in Mathematics Education, 20, 498-505.

Stacey, K., Helme, S., Steinle, V., Baturo, A., Irwin, K., \& Bana, J. (2001). Preservice teachers' knowledge of difficulties in decimal numeration. Journal of Mathematics Teacher Education, 4, 205-225.

Staub, F. C., \& Stern, E. (2002). The nature of teachers' pedagogical content beliefs matters for students' achievement gains: Quasi-experimental evidence from elementary mathematics. Journal of Educational Psychology, 94, 344-355.

Stipek, D. J., Givven, K. B., Salmon, J. M., \& MacGyvers, V. L. (2001). Teachers' beliefs and practices related to mathematics instruction. Teaching and Teacher Education, 17, 213-226.

Stipek, D. J., Salmon, J. M., Givvin, K. B., Kazemi, E., Saxe, G., \& MacGyvers, V. L. (1998). The value (and convergence) of practices suggested by motivation research and promoted by mathematics education reformers. Journal for Research in Mathematics Education, 29, 465-488.

Strauss, R. P., \& Sawyer, E. A. (1986). Some new evidence on teacher and student competencies. Economics of Education Review, 5, 41-48.

Thompson, A. G., \& Thompson, P. W. (1996). Talking about rates conceptually, part II: Mathematical knowledge for teaching. Journal for Research in Mathematics Education, 21, 2-24.

Turner, J. C., Meyer, D. K., Midgley, C., \& Patrick, H. (2003). Teacher discourse and sixth graders' reported affect and achievement behaviors in two high-mastery/high-performance mathematics classrooms. Elementary School Journal, 103, 357-382.

U.S. Department of Education. (2002). Meeting the highly qualified teachers challenge: The Secretary's annual report on teacher quality. Washington, DC: U.S. Department of Education, Office of Postsecondary Education, Office of Policy, Planning, and Innovation. Retrieved October 4, 2006, from http://www.ed.gov/about/reports/annual/teachprep/2002title-ii-report.pdf

Valli, L., \& Agostinelli, A. (1993). Teaching before and after professional preparation: The story of a high school mathematics teacher. Journal of Teacher Education, 44, 107-114.

Von Secker, C. (2002). Effects on inquiry-based teacher practice on science excellence and equity. Journal of Educational Research, 95, 151-160.

Wayne, A. J., \& Youngs, P. (2003). Teacher characteristics and student achievement gains: A review. Review of Educational Research, 73(1), 89-122.

Wenglinsky, H. (2002). How schools matter: The link between teacher classroom practices and student achievement. Educational Policy Analysis Archives, 10(12). Retrieved February 24, 2007, from http://epaa.asu.edu/epaa/v10n12/

Wenglinsky, H. (2004). Facts of critical thinking skills? What NAEP results say. Educational Leadership, 62(1), 32-35.

Wilson, S., \& Floden, R. E. (2003). Creating effective teachers: Concise answers for hard questions. An addendum to the report "Teacher Preparation Research: Current Knowledge, Gaps, and Recommendations." Denver, CO: Education Commission of the States. (ERIC Document Reproduction Service No. ED 476366)

Wilson, S. M., Floden, R., \& Ferrini-Mundy, J. (2001). Teacher preparation research: Current knowledge, gaps, and recommendations. A research report prepared for the U.S. Department of Education. Seattle: Center for the Study of Teaching and Policy, University of Washington. Retrieved March 2005 from http://www.ctpweb.org/ 